\title{
1차원 $\mathrm{Cu}$ (II) 배위 고분자의 합성 및 구조: [Cu(bdcH) $\left.)_{2}(\mathrm{bipyen})\right]$ (bdc=1,3-benzenedicarboxylate; bipyen=trans-1,2-bis (4-pyridyl)ethylene)
}

\author{
李娟垌 · 李順遠 ${ }^{*}$ \\ 성규관대학교 화학과 \\ (20)(12. 7. 28 접수)
}

\section{Preparation and Structure of One-Dimensional Copper(II) Coordination Polymer: [Cu(bdcH $)_{2}($ bipyen $\left.)\right]($ bdc $=1,3-$ benzenedicarboxylate; bipyen=trans-1,2-bis(4-pyridyl)ethylene)}

\author{
Yeon Kyoung Lee and Soon W. Lee*

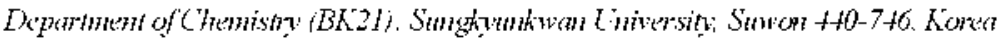

(Received July 28. 2002)

주제어: 1차원. Copper(II). Bdc. Bipren

Keywords: One-I)imensional, Copper(II), I3de. J3ipyen

Recintly, a varity of exordination polymers basod on metal-ligand coordinative covalent honding have received considerable attraction due to their novel topologies and intertsting lunctions. ${ }^{1-6}$ In particular; research interest has hoen locused on porous highdimensional coodination polvmers, because of their potential zeolite-like applications. ${ }^{-10}$ For the prepatation of this type of polymers, 1,3,5-benzenetricatbonylic acid (btcl $l_{3}$ ) is widely employed because of its potential role as a multidimensional ligand..$^{11-1.3}$

We have been continualy interested in preparing corordination polymers with dicarboxylate ligands. For instance, we bave obtained a $3-D$ rine ${ }^{11} 3-D$

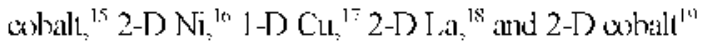
coordination polymers by hydrothemal reactions. Very racently, we reported the structure of $\left\lceil\mathrm{Cu}(\mathrm{btch})_{2}\right)_{2}$ (bpy)], which was hydrothermally prepared from copper nitrate $\left(\mathrm{Cu}\left(\mathrm{NO}_{3}\right)_{2} \cdot 2.5 \mathrm{I}_{2} \mathrm{O}\right)$, btch $\mathrm{H}_{3}$, and 4.4 bipytidine (byy). Interestingly, this polymer has a one-dimensional network despite the potential of the btcl $\mathrm{l}_{3}$ as a multidimensional ligand. ${ }^{2 n}$

In order to gain more insight into the connectiv- ity paltern and its ensuing structures of the mixedligand sysems of carboyylates and pyridyls. we decided to prepare another eopper coordination polymer hased on 1,3-henanedicarboxylic acid (ixophtalic acid, bdeH, and trans-1,2-his(4-pyricty)ethylene (bipren). The hydrothemal reaction of $\mathrm{Cu}\left(\mathrm{NO}_{3}\right)_{2} 2.5 \mathrm{I}_{2} \mathrm{O}$ with bdcl $\mathrm{I}_{2}$ and biryen gave a one-dimensional coordination polymer with an empirical fomula of [ $\left.\mathrm{Cu}(\mathrm{bdel})_{2}(\mathrm{birsen})\right]$ (1). I lereir. we report the preparation, structure and themal property of polymer 1.

\section{EXPERIMENTAL SECTION}

$\mathrm{Cu}\left(\mathrm{NO}_{3}\right)_{2} \cdot 2.5 \mathrm{H}_{2} \mathrm{O}$, bde $\mathrm{H}_{2}$ and bipven were purchased. IR spectra were recorded with a Nicolet Avatar 320 Fl-IR spectrophotometer: Themogravimetric analyses were carried out on a $\mathrm{T} 44000 / \mathrm{SD} \mathrm{T}$ 2960 instrument. Elemental analyses were performed by the National Center for Inter-University Research Facilities

Preparation of $\mathrm{Cu}(\mathrm{bdcH})_{2}(\mathrm{bipyen})(1) . \Lambda$ mix- 
thre of $\mathrm{Cu}\left(\mathrm{NO}_{3}\right)_{2} 2.51 \mathrm{l}_{2} \mathrm{O}(0.175 \mathrm{~g}, 0.602 \mathrm{mmol})$. bed $\mathrm{I}_{2}$

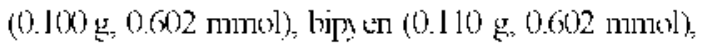
and $\mathrm{H}_{2} \mathrm{O}(6 \mathrm{mI}$.) in the mole ratio of $1: 1: 1: 700$ was heated in a 23-mI. Tellon-lined reaction vessel at 150 " $\mathrm{C}$ for 2 day s and then cooled to room temperature by arr-cosling. The blut product was collected by filtuation, washed with $\mathrm{H}_{2} \mathrm{O}(2 \times 5 \mathrm{mI})$ and ethanol $(2 \times 5 \mathrm{~mL})$, and then air-dried to give blue crystals of Cu(budel 1) (bipen) (0.141 g. $0.203 \mathrm{mmol}$, $80.8 \%$ yield). Anal. Calcd for $\mathrm{C}_{28} \mathrm{I}_{18} \mathrm{~N}_{2} \mathrm{O}_{12} \mathrm{Cu}\left(\mathrm{M}_{\mathrm{r}}=\right.$ 576.00): C, 58.39: N, 4.86: 11, 3.50. Found: C, 58.22: N, 4.89: II. 3.52. IR (KBr): 3440, 3012, $1864,1697,1626,1573,1425,1371,1261,1159$, $1067,934,827,798,730.555 \mathrm{~cm}^{-1}$.

$\mathrm{X}$-ray Structure Determination. All X-ray data "lere collected with the use of a Siemens P4 dillractomoter sequipped with a Mo X-ray lube and a graphite monochromator. The orientation matrix and unit-cell parameters were determinod by the least-squares analy'ses of the setting angles of 24 reflections in the range of $10.0^{\circ}<2 \theta<25.0^{\circ}$. Three check-teflections were measured erery 100 reflections throughout data collection and showed no noticeable variations in intensity: The intensity data were empirically conected for absorption with $\psi$ sean dalat. Dheay corrections were also made. All calculations were carried out with the use of SHГI, XTI. programs. ${ }^{21}$

A blue erystal of 1 , shaped as a block of approximate dimensions of $0.30 \times 0.28 \times 0.14 \mathrm{~mm}^{3}$, was used for erystal- and intensity-datal collection. The unitcell parameters and svstematic absences of $h(t) /=$ $2 n+1)$ and $O K O(k=2 n+1)$ unambignously indicated $P 2 / C$ as a space group. The structure was solved by direct methods. All non-hydrogen atoms were retíned anisotropically: All hydrogen atoms were located in the ditterence fourier maps and were relined isolropically. Details on erystal data and
Table 1 . X-ray data collection and stucture relinement

\begin{tabular}{|c|c|}
\hline formula & $\mathrm{C}_{2 i} \mathrm{HI}_{i 1} \mathrm{CuN}_{i} \mathrm{O}_{*}$ \\
\hline tiv & 576.00 \\
\hline temperature. $\mathrm{K}$ & $293(2)$ \\
\hline cr্silal system & monoclinic \\
\hline space group & $P 2_{1}: c$ \\
\hline a. $\AA$ & $11.529(2)$ \\
\hline b. $\AA$ & $13.575(2)$ \\
\hline c. $\AA$ & $15.908(4)$ \\
\hline B. deg & $106.41(2)$ \\
\hline $1: \AA^{3}$ & $2388.2(8)$ \\
\hline 7. & 4 \\
\hline$d_{\mu:} \cdot \mathrm{g} \mathrm{cm}{ }^{t}$ & 1.602 \\
\hline H. $\mathrm{mm}$ & 0.974 \\
\hline$T_{\text {rmun }}$ & 0.7200 \\
\hline$T_{\text {trias }}$ & 0.9212 \\
\hline$F(000)$ & 1180 \\
\hline $2 \theta$ range $\left({ }^{\circ}\right)$ & $3.5-50$ \\
\hline $\operatorname{scan} \operatorname{typ}$ & (1) \\
\hline scan sprecd & variable \\
\hline No. of retlos measured & 4.366 \\
\hline No. of retlos unicuc & 414.3 \\
\hline No. of retles with $I \cdot 2 \sigma(l)$ & 3041 \\
\hline No. of params retincd & 4.32 \\
\hline Max. in $\Delta \rho\left(\mathrm{c} \lambda^{-i \grave{j}}\right.$ & 0.2 .35 \\
\hline Min.. in $\Delta \rho\left(\mathrm{c} \Lambda^{-3}\right)$ & -0.317 \\
\hline GOF on $\mathrm{F}^{2}$ & 1.048 \\
\hline$R$ & 0.0385 \\
\hline$w R_{2}^{4}$ & 0.0814 \\
\hline
\end{tabular}

${ }^{a} w R_{1}-\Sigma\left|w\left(F^{\prime}-F^{\prime}:\right)^{n}\right| \Sigma\left|w\left(F^{*}=\right)^{\prime}\right|^{1: 2}$

relinement details are given in Fabte 1. Selected hond lengths and bond angles are given in Table 2 .

Crystallographic data for the structural analysis have been deposited at the Cambridge Crystallographic Data Center CCDC No. 190620 for 1. Copies of this information may be obtained free of charge from: The director CCDC, 12 Union Road, Cambridge, CB2 lEL, UK (Fax: +44-1223-336-033: E-mail: depositiciccdc.camac.uk or wuw: htpp// nuwecde.cam ac.uk/conts/retricring.html).

Table 2. Selected bond lengths ( $A$ ) and bond angles (")

\begin{tabular}{lccccc}
\hline \hline Cul-O1 & $1.916(2)$ & CulO5 & $1.926(2)$ & CulN1 & $2.082(2)$ \\
Cul-N2 & $2.091(2)$ & & & & \\
\hline O1-Cu1-05 & $177.33(9)$ & OlCul-N1 & $89.79(9)$ & O5CulN1 & $90.57(9)$ \\
O1-Cul-N2 & $89.55(9)$ & O5Cul-N2 & $90.20(9)$ & NICulN2 & $177.48(10)$ \\
\hline
\end{tabular}




\section{RESULTS AND DISCUSSION}

Preparation. A one-dimensional Cu(II) coordination polymer with an empirical lomula of $[\mathrm{Cu}$ (bdeH) (bipyen)] (1) was prepared by heating a mixtune of $\mathrm{Cu}\left(\mathrm{NO}_{3}\right)_{2} 2.5 \mathrm{H}_{2} \mathrm{O}, \mathrm{bdeH}_{2}$, hipyen, and $\mathrm{H}_{2} \mathrm{O}$ in the mole ratio of 1:1:1:700 at $1500^{\circ} \mathrm{C}$ for 2 days (eq l). A very closely related polymer $[\mathrm{Cu}$ (btcl $\left.\left.l_{2}\right)_{2}(\mathrm{bpy})\right]$ was recently reported by our group. ${ }^{20}$

$$
\left.\mathrm{lCu}\left(\mathrm{NO}_{3}\right)_{2}\right) 2.5 \mathrm{I}_{2} \mathrm{O}+2 \mathrm{bdcl}_{2}+\text { bipven } \longrightarrow 2 \mathrm{INO}_{3}+
$$

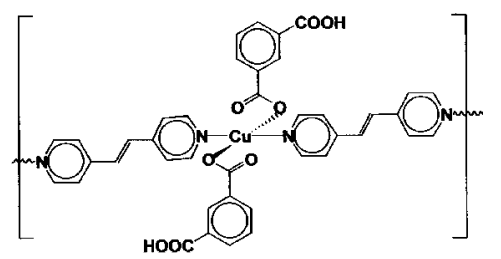

The compound $\mathbf{I}$ is air- and moisture-stahle and is not soluble in common organic solvents. The IR spectrum of 1 shows the asvmmetric and stmmettic carboxylate stretches for bdcll ' (1697, 1626 , 1573. and $1371 \mathrm{~cm}^{1}$ ).2.23 The shift of the carbonyl bands in the tree bdcI $I_{2}$ and the disappearance of some characteristic bands ( 1592 and $\left.1460 \mathrm{~cm}^{1}\right)$ in the free bipys suggest that hoth bde $\mathrm{H}_{2}$ and hipyen might have betn coordinatod to copper metals during the reaction. A broad band at $3440 \mathrm{~cm}^{-1}$ can be assigned to the $\mathrm{OH}$ siretch in the uncoordinatod car-

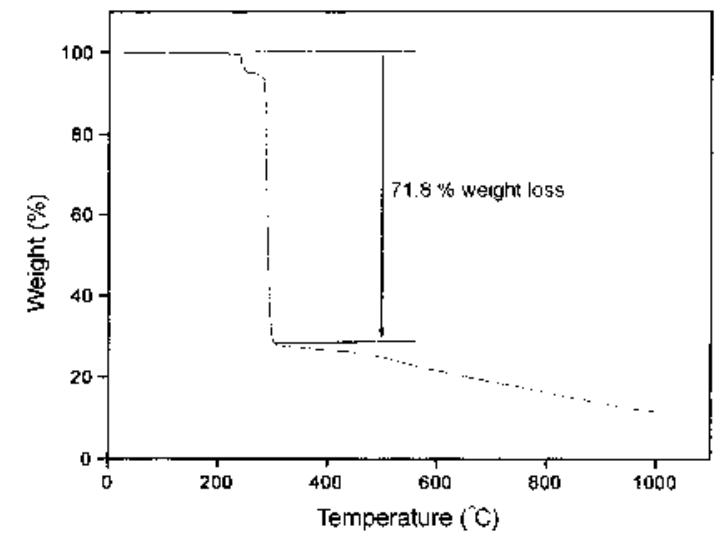

Fig. l. Thenmogravimetric analysis results for $\mathbf{1}$

hoxylate group. The formulation of 1 has been lurther conlimed by X-ray dilliraction and elemental analy sis.

Themogravimetric analy sis (TCA) shows that the title polyner is stable up 10240 "C without decomposition $\left(F_{g} g .1\right)$. $A$ drastic weight loss occurs from 280 to $305^{\circ} \mathrm{C}$, which corresponds to the loss of two bdell ligands and one bipyen ligand. In comparison, the $\left\lfloor\mathrm{Cu}\left(\mathrm{btcl} \mathrm{I}_{2}\right)_{2}(\mathrm{~b} p \mathrm{x})\right\rfloor$ polymer related to polymer $\mathbf{l}$ is stable up to $2800^{\circ} \mathrm{C} \mathrm{C}$.

Structure. Fig. 2 shows the local coordination of the copper eenter. The coordination sphere of copper can be described as square planar. with two oxygen atoms from two hde $\mathrm{H}^{-}$ligends and two nitrogen atoms from wo hipyen ligands. The hor-

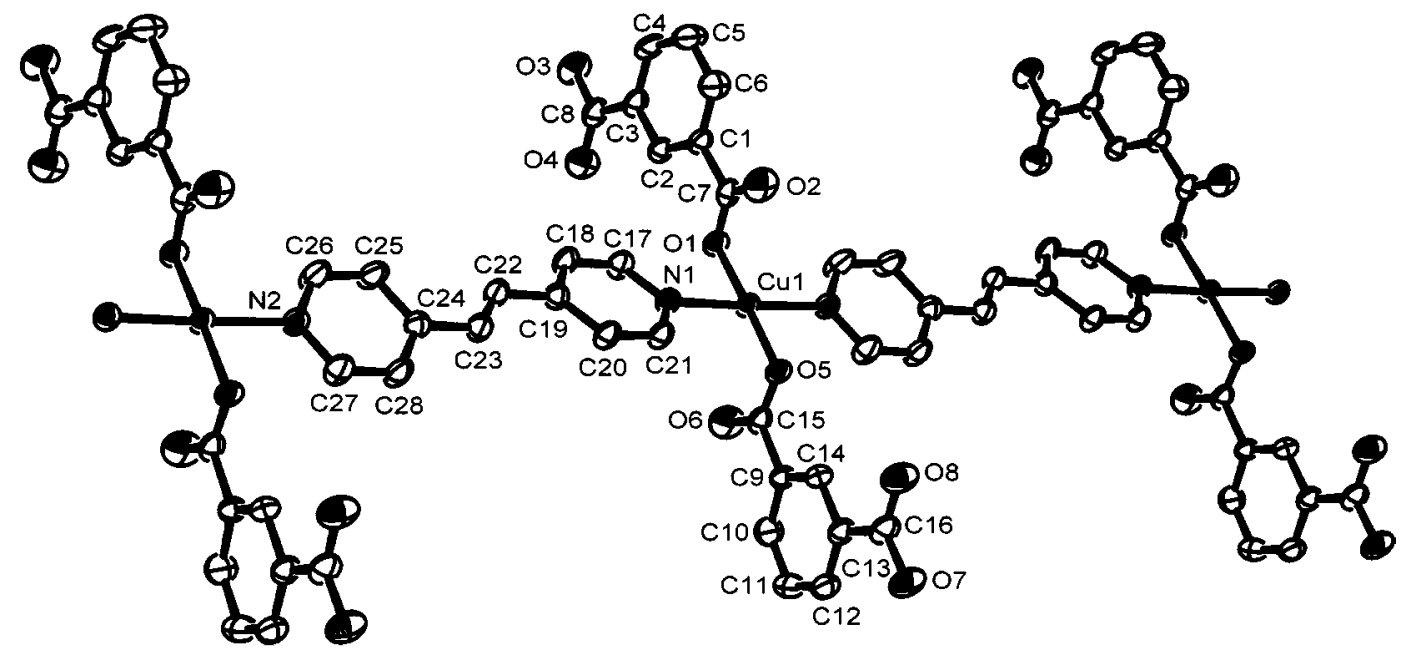

Fig. 2. ORTFP druning of 1 showing the atom-labeling scheme and $50^{\circ}$ o probability thenmal ellipsoids. 


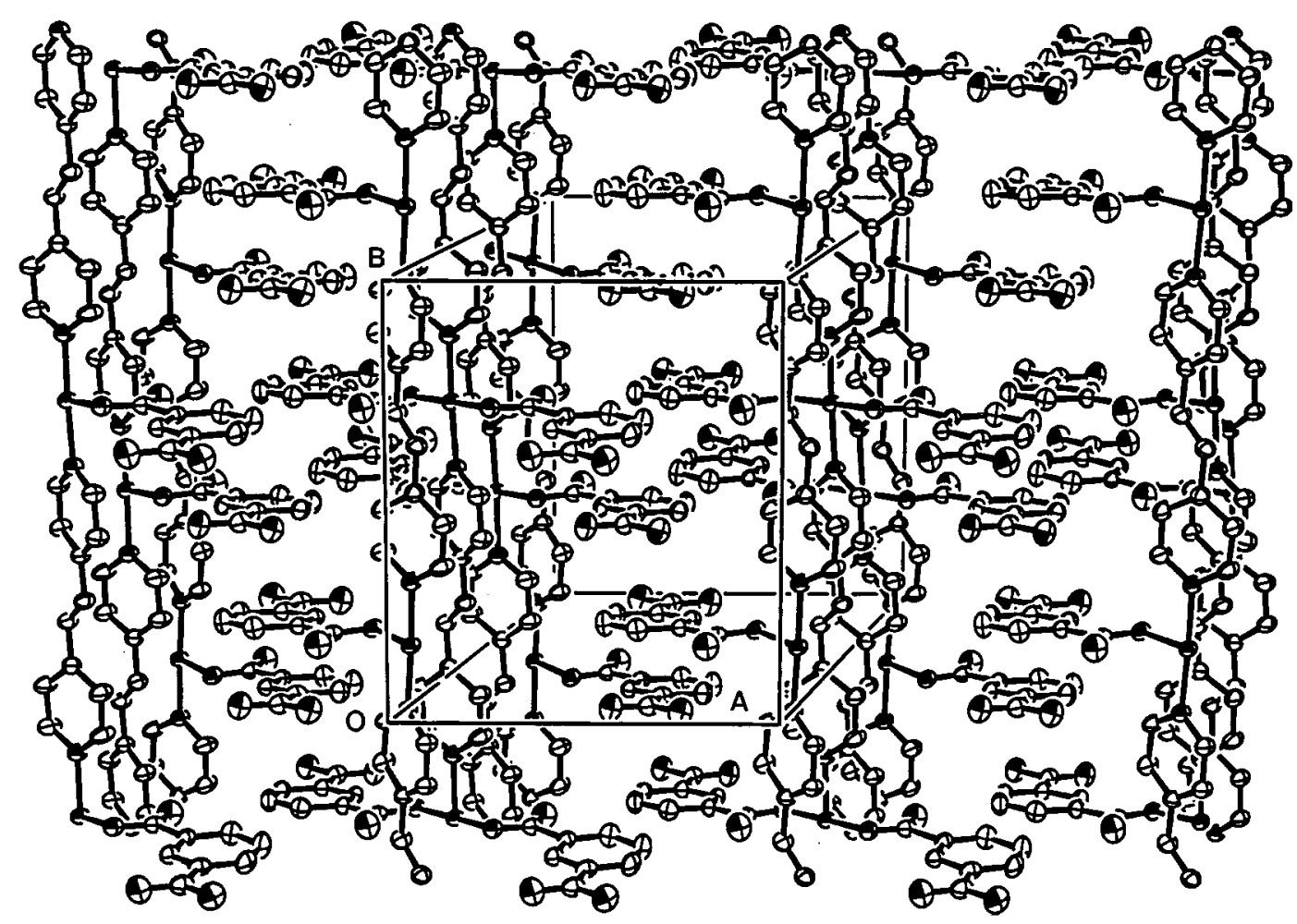

Fig. 3. A packing diagram along the c-axis.

mal oxidation state of the copper metal is +2 . The $\mathrm{C}-\mathrm{O}$ bond lengths in the coordinated and uncoordinated carboxylate groups are equal within experimental stror.

The equatorial plane delined by Cul, N1, N2, Ol, and 05 , is relatively planar with an average alomic displacement of $0.0443 \AA$. Two pyridine moletics in the bijyen ligand ate twisted from each other by $17.9(2)^{\circ}$. The benzene ring in the bdel 1 ligand is almost planat with an average atomic displacement of $0.0007 \hat{\Lambda}$ and is essentially perpendicular to the equatotial plane with a dihedral angle of $87.0(1)^{\text {r }}$. The bipwen acts as a bridging ligand between two Cu melals. Interestingly the hde $\mathrm{H}^{-}$ligand acts as a monodentate oxygen-domor ligand and does not link Cu melals: that is only one (OI) out of the four carboxylate oxygens in the bde $\mathrm{H}^{-}$ligand is coordinated to the copper metal.

The packing diagram along the $c$-axis demonstrates a one-dimensional polymeric structure of 1 (Fig. 3). Each one-dimensional array is fomed by the bridging bipyen ligands linking $\mathrm{Cu}$ metals in the $b$-axis direction. Thexe 1-D antays stack on top of each other along the $c$-axis. The hydrogen atsms in the uncordinated earhoxylate groups are involved in intermolecular hydrogen honds: $03-\mathrm{HO}=1.139$ A. $03 \cdots 08=2.601 \AA$ A HO3 $\cdots 08=1.465 A$. and $03-$ $\mathrm{HO} 3 \cdots \mathrm{O} 8=175.57^{\circ}: \quad 07-\mathrm{HO}=1.325 \AA, \quad 07 \cdots \mathrm{O} 4=$ $2.668 \Lambda, 1107 \cdots 04=1.343 \Lambda$, and $07-[107 \cdots 04=$

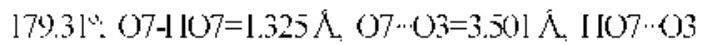
$=2.621 \Lambda$, and $07-1107 \cdots 03=121.57^{\circ}$. The overall bonding parameters and tramework pattern of 1 are essentially the same as those found for $\left[\mathrm{Cu}\left(\mathrm{btcl} I_{3}\right)_{2}\right.$ (bpy)] that we previously reported. ${ }^{20}$ Chen and coworkers very recently reported an intriguing result that the hydrothermal reaction of $\mathrm{Cu}\left(\mathrm{NO}_{3}\right) 3 \mathrm{H}_{2} \mathrm{O}$ with hde $\mathrm{H}_{2}$ and $\mathrm{bpy}$ at $180^{\circ} \mathrm{C}$ galve a 3-dimensional, mixed-ralence $\mathrm{Cu}(\mathrm{T}, \mathrm{IT})$ polymer $\left[\mathrm{C} \mathrm{u}_{2}(\mathrm{hdcO})\right.$ -

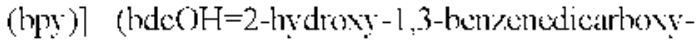
late) ${ }^{\text {t- }}$ They rationalized the fomation of the bde $0^{3}$ fragment on the basis of the in situ oxidation of the bdc $c^{2}$ ion under the hydrothermal condi- 
tions. $\mathrm{By}$ contrast, our reaction system consisting of $\mathrm{Cu}\left(\mathrm{NO}_{3}\right)_{2} 2.5 \mathrm{H}_{2} \mathrm{O}$, bdeH $\mathrm{H}_{2}$, and bipyen at $150^{\circ} \mathrm{C}$ gave a 1-dimensional copper(II) coordination polymer; and the oxidation of bdeH- ligand was not observed.

In summany, we have structurally characterized $\mathrm{Cu}(\mathrm{bdeH})_{2}(\mathrm{hipyen})$ (1), which was prepared by the hydrothermal reaction of $\mathrm{Cu}\left(\mathrm{NO}_{3}\right)_{2} \cdot 2.5 \mathrm{I}_{2} \mathrm{O}$ with the mixed ligands of 1.3-benzenedicarbonylic acid (bdel $\mathrm{l}_{2}$ ) and trans-1,2-bis(4-prridyl)ethylene (bipven). 'lhis polymer has a one-dimensional network and exhibits thermal stability up to $240^{\circ} \mathrm{C}$ '.

Acknow ledgment. This work is based on restarch sponsored by the Korta Foundation Grant (KRF-2001-015-DP0262).

\section{REFERENCES}

1. Desiraju. G. R. Cinstal Enginesting: The Design of Organic Solids: Tilsevier: New York. 1989; Vol. 54

2. Batten, S. R.: Robson, R. ingew. (Whem. Int. Fd. Fingl. 1998. 37, 1461.

3. I Jagman, P. J.: I Iagman, D.: 7.ubicta. J. ingew. (Them. Iht Fd. 1999, 38, 2638.

4. Yaghi, O. M.: I.i, I1:- Davis, C.: Richardson. D:- Grov: T. I.. icc. (hem. Re's 1998, 31, 474.

5. Evans. O. R. Lin. W. Hong. Chem. 2000. 39. 2189.

6. Exans. O. R.: Lin. W. Crustat Gnomh \& Design 2001. I. 8.

7. Janiak. C. Angew: Chem. Int Ed. Engl 1997. 36. 1431.

8. Munakata. M.: Wu. L. 1:: Kuroda-Sowa. 1. At horg. Chem. 1999. 46. 173

9. Chui. S. S.-Y.: Lo. S. M.-F.: Charman1. đ. 1'. H.: Orpen.
A. G.: Williams. 1. D. Scionce 1999. 283. 1148.

10. Kiang. Y.-H.: Gardner. G. B.: Lee. S.: Xu. La: Lobkorshy. E. B. J. Am. Ch'm. Soc. 1999. 121. 8204.

11. Kim. „. H.: Chen. B.: Reineke. I: M.: Li. H.: Eddaoudi. M.: Moler. D. B.: OKeelle. M.: Yaghi. O. M. $J . A m$. (hem. Soc. 2001. 123.8239.

12. Г.ddaoudi, M.: I.i. II: Yaghi. O. M. J. Lm Chem. Soc 2000. 122, 1391

13. Yaghi, O. M.: I.i. H.: Groy. T. I.. J. Lhe Chem Soc 1996. 118,9096

14. Min. D: Yoon. S. S.: I. $\infty$. C. Y: Suh. M.: I Iwang. Y.I. I Jan, W. S.: I $\infty, \mathrm{S}$. W. Bull Koman Chom Soc. 2001. 22. 531 .

15. Min. D.: Yoot, S. S.: I ce, I. II.: Suh, M.: I ce. S. W. lhorg. (hem. Conmmin 2001. 4, 297.

16. Mitn. D.: Yootn. S. S: I ce. C. Y: I Ian. W. S. I.⿻. S. W. Bull Nowew (hem. Soc. 2001, 22, 1041.

17. Min. D.: Yom. S. S.: Jung. D. Y: Lee. C. Y.: Kim. Y.: Han. W. S.: Lee. S. W. Inomg. Chm. deta 2001. 324. 293.

18. Kim. H. J.: Min. D.: Hox. H. S.: Lee. S. W. J. Konm Chem. Soc. 2001. 45.507.

19. Min. D.: Yom. S. S.: Lee. S. W. Inong. Chm Commim. 2002. 5.143 .

20. Hul. H. S.: Min. D. W.: Lee. Y. K.: Lee. S. W. Bull. Sonan Chrm. Soc. 2002. 23.619.

21. Bruker. SHELXTL. Strtate Dethmination Softwat Programs. Bruker Analytical X-ray Instruments lnc.. Madison. Wisconsin. USA. 1997.

22. Melrohra. R. C.: Bolira. R. Metal C'abontates: Academic l'ress: New York. 1983.

23. Gordon. A. I.: Ford, R. A. The Chemist's Compation: .1 Handhook of Practical Data, Techiniques, and Refewees: Wilcy: New York, 1972.

24. Tao, J.: 7.hang. Y: Tong, M.-J.: Chen, X.-M.: Yuen. T.: J.in. C. I... I Iuang. X.: I. i. I. Chem. Comm 2002, 1.342. 